\title{
Wood Anatomy in Several Genera of Nigerian Annonaceae
}

\author{
Olusanya Abiodun OLATUNJI
}

\author{
Department of Botany, Obafemi Awolowo University Ile-Ife, Osun State, Nigeria; \\ olusanya084@yahoo.ca
}

\begin{abstract}
The anatomical characteristic of the wood of Annona muricata, A. senegalensis, Xylopia aethiopica, A. glauca, A. squamosa, Cleistopholis patens, Monodora tenuifolia and Greenwayodendron suaviolis were investigated in search of their stable taxonomic attribute. Thirty-two wood samples were collected from eight species of Annonnaceae (four specimens each). Fixation of the most healthy and fresh wood of each species was done using $500 \mathrm{ml}$ of FAA (Formalin Acetic Acid) and dehydrated in a series of ethanol while infiltration was done using tertiary-butyl-alcohol prepared in accordance with Johansen's method. The sectioning was carried out with a rotary microtome and the slide containing the wood samples were examined using power shots s70 camera attached to computer. The results revealed several interesting wood anatomical features such as the presence of numerous fibre, ray cells, vessels, absence of axial parenchyma in some species, growth ring ranges from distinct to indistinct. Rays are composed of upright cells in $A$. muricata, fibre tracheid are also uncommon in $A$. muricata but common in $G$. suaviolis. Axial parenchyma are common in $A$. glauca and $A$. squamosa but absent in other species. The wood structure of $A$. glauca and $A$. squamosa are similar to that of $C$. patens, but the absence of axial parenchyma distinguished it from them. The results are important in understanding the relationships between and within the species.
\end{abstract}

Keywords: annona, anatomical character, anticlinical wall, comparative study, leaf epidermal morphology

\section{Introduction}

Annonaceae family is a family of flowering plant consisting of trees, shrub or rarely woody lianas with nearly 2,300 to 2,500 species and more than 130 genera (Bridg, 1993 a). The family is also called Custard apple family. This family is closely related to the family Ranunculaceae. However, Annonaceae is more primitive than Ranunculaceae. The family is concentrated in the tropics, with few species found in temperate region. About 900 species are Neotropical, 450 are Afro tropical and other species are Indomalayen (Erkens et al., 2007). According to Su et al. (2008), pollination of the more or less odoriferous flower in neotropical Annonaceae, is mainly by a variety of beetles, although pollination by flies and thrips were also known; there is considerable variation in the scent produced (Goodrich and Raguso, 2009). Leaves are alternate, simple without stipules and have leaf stalks. The leaf blades consist of several leaflets, or separate portions, arranged on each side of a common leaf stalk separated by veins. Flowers stalk start from leaf scars on old wood and from leaf on new shoots. The family may have small bundles that grow from peduncle (leaf stalk) or solitary flowers. Flowers are usually bisexual and rarely unisexual; the apex of the flower stalk from which the organs of the flower grow might become elevated, enlarged, or flat. The wood anatomy of the family is very uniform and the genera, with exception of Asimina, are not easily distinguishable. The high level of specialization observed in this family may be attributed to simple perforation and mean member length of the vessels, the frequently storied parenchyma and the scarcity of uniserate rays. Light Microscope has been used to study leaf epidermal morphology of West Africa species of Monodora tenuifolia and the epidermal cell are noted to either be isodiametric or irregular in shape. All taxa have paracytic stomata which are hypostomatically distributed while the anticlinical wall may be straight, curved, or undulating. Several studies had been carried out on the genus Annona but there had been no report on the diversity of the stem anatomy and tissues of the various species in the family. According to Olatunji (1992), the close similarities observed among woody species in many of their wood anatomical features may be employed to delimit them; studies of this nature might facilitate identification of taxa most importantly when their reproductive parts are not available. This would enable both taxonomists and the general public to have faint idea of this plant and possible means of conserving them (Folorunso, 2011).

However, the objective of this research work is to carry out anatomical studies on eight different species of Annonaceae which are $A$. squamosa, $A$. senegalensis, 
A. muricata, A. glauca, Monodora tenuifolia, $X$. aethiopica, $C$. patens and $G$. suaviolis and compare them with each other to know their differences and ascertain their similarity based on presence of some taxonomic character.

\section{Materials and Methods}

Thirty-two wood samples were collected from eight species of Annonnaceae (four specimens each). Six species were collected from University of Ibadan Botanical Garden (Annona squamosa, A. muricata, Monodora tenuifolia, Xylopia aethiopica, Cleistopholis patens and Greenwaydendron suaviolis) while the remaining two species were collected from University of Agriculture, Abeokuta Botanical Garden (Annona glauca and Annona senegalensis).

The whole experiment was carried out within the University of Agriculture, both in the biological science laboratory and college of veterinary medicine laboratory. The most healthy and fresh wood of each species were revived by boiling in water for 20 minutes and fixed in $500 \mathrm{ml}$ of Formalin-Acetic-Alcohol (FAA) for 24 hours followed by dehydration in series of ethanol. Infiltration was done with using TertiaryButyl-Alcohol (TBA) as base at 450c. Infiltrated specimens were then transferred into the embedding liquid (melted wax poured into improvised moulds) to cast hard blocks. The species to be sectioned were fastened to a mounting block, which is clamped into the microtone and the Paraffin wax around the materials was trimmed so that the cutting plane is established. The materials were sectioned with approximately $10 \mu \mathrm{m}$ (micron) in order to show details of each cell and to improve transparency. The sectioned materials were transferred into drops of warm distilled water on a clean slide on which egg adhesive had been previously rubbed. The slides were then dry to ensure proper adherence. The sectioned affixed to the slide were then pass through xylene for proper de-waxing. Staining was done with Safranin O for 15 minutes and then dehydrates it by passing the slide through different grades of alcohol, 30\%, 50\%, $70 \%$ and $95 \%$ respectively. They were then transferred into the fast green for counter staining for 2 seconds after which they were dehydrated in absolute alcohol. The stained specimens were later put in clove oil for clearing and then xylene for about 5 minutes. They were then air dried and later covered with the cover slip using one drop of DPX as mutants. The slide containing the wood samples were examined using power shots 570 camera attached to computer at magnification of 10 and photomicrographs were taken to show the wood anatomical features of the species studied.

\section{Results}

Figs. 1-10 show the anatomical features of the woods studied. The woods are ring-porous to semiring porous with distinct growth ring boundary in (Figs. 1, 4 and 5) while in (Figs. 2, 3, 8, 9 and 10) the growth rings are indistinct, diffuse and porous.
Epidermis and cortex are clearly outlined in all the species studied.

In Cleistopholis patens, $A$. glauca and $A$. muricata (Figs. 1, 5 and 9) the vessels are predominantly solitary, sometimes in short radial or tangential multiples while in $A$. squamosa and $A$. senegalensis (Figs. 4 and 8 ) vessels are exclusively solitary. In $G$. suaviolis, the vessels are numerous but not clearly outlined. However in M. tenuifolia and $X$. aethiopica vessels are in small clusters as well as short tangential. Vessels outlines in (Figs. 1, 4, 5, 8, 9 and 10) ranges from angular to rounded, or circular to rounded while in Monodora tenuifolia and Greenwayodendron suaviolis (Figs. 2 and 3 ) the outlines are not clearly shown. Vessels perforation plates are simple to compound with a few scalariform perforation plates of two to three bars in (Figs. 1, 4, 5, 8 and 10). In $A$. muricata, vessels perforation plates are exclusively reticulate with intervessel plates near each other (Fig. 9). Vessels pit are angular to oval in Monodora tenuifolia (Fig. 2), and distinctly bordered in $A$. senegalensis and $A$. muricata (Figs. 8 and 9) with intervessel pits opposite to each other in $A$. senegalensis and $X$. aethiopica (Figs. 8 and 10), or near each other in $A$. muricata (Fig. 9). In $A$. muricata (Fig. 9), vessel rays are numerous and sometimes scalariform while in $X$. aethiopica vessel-rays are similar to intervessel pits in arrangements and distinctly bordered in $A$. muricata. Fibres are numerous and non septate with distinctly bordered common on radial and tangential wall (Figs. 5 and 10). In A. muricata, phloem fibre is present and fibre pit distinctly bordered but tracheid is lacking (Fig. 9).Tracheids are rare, as well as fibre-tracheids. In $A$. senegalensis and $A$. muricata (Figs. 8 and 9), tracheid are common and the vascular trachied intergrading with narrow vessel elements are present in $X$. aethiopica (Fig. 10) and $M$. tenuifolia (Fig. 2). Tracheids are present and clearly outlined in $A$. senegalensis (Fig. 8) and the fibretracheids are also common with pit distinctly bordered. Axial parenchyma are sparsely present, diffuse and sometimes fusiform (Figs. 3 and 9). Rays are exclusively uniseriate (Figs. 1, 2, 4, 5, 8 and 10) but sometimes multiseriate (Figs. 3 and 9) with upright ray cells, and sheath cells are present in parts of some rays. Vessel ray perforation and storied ray structure are present in $X$. aethiopica (Fig. 10) and A. muricata (Fig. 9). Piths are common to all the species studied with the pith cells being numerous and oval to circular in outline. In $C$. patens (Fig. 1), pith cells are mostly angular and distinctly bordered, while in $G$. suaviolis (Fig. 3), the pith cells are present but not clearly outlined. In $A$. muricata (Fig. 9), they are mostly angular and the smaller cells scattered between larger cells. Since most vessel are solitary and generally embedded in fibre tissue, the pits are vessel-fibre pits and occasionally vessel-parenchyma pits. Apart from vessels and tracheids, vestured pit is also observed in fibre of $G$. suaviolis (Fig. 3). Vestures are also more common in narrow vessel elements. Small vessel-ray 
127

pit are frequently vestured, while larger vessel-ray pits often lack vestures. However, the dimension of the wood and their qualitative anatomical features were shown in Tab. 1 and 2 respectively. The measurement of the dimension of the tissues of the woods revealed differences among the species in vessel diameter and
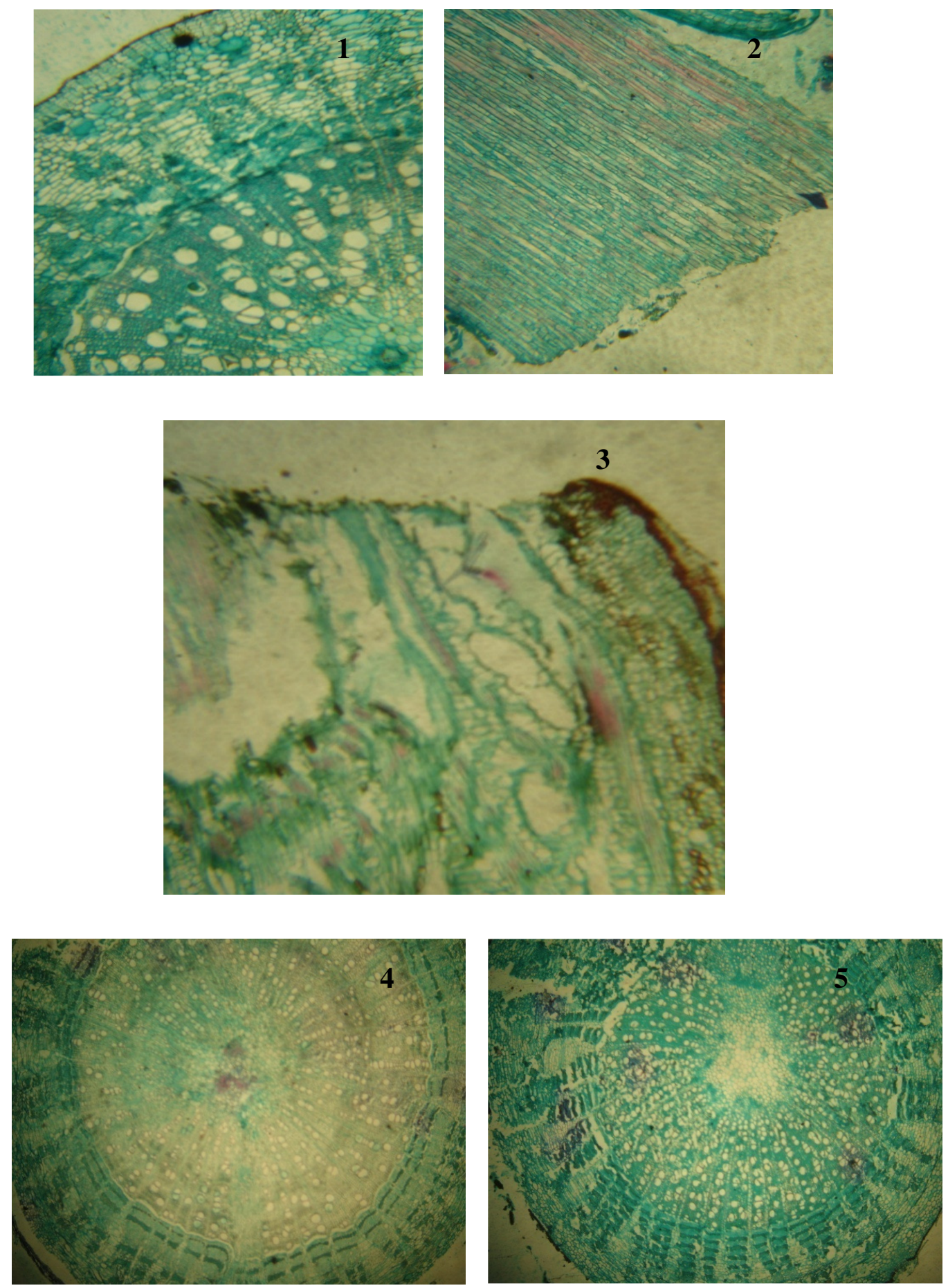

Fig. 1. The transverse section of the anatomical feature of Cleistopholis patens. Fig. 2. The longitudinal section of anatomical feature of Monodora tenuifolia. Fig. 3. The transverse section of $G$. suaviolis with the tracheid clearly outlined while. Fig. 4. The transverse section of the anatomical feature of Annona squamosa at magnification of $\times 4$. Fig. 5. The transverse section of the anatomical feature of $A$. glauca at magnification of $\times 4$. 

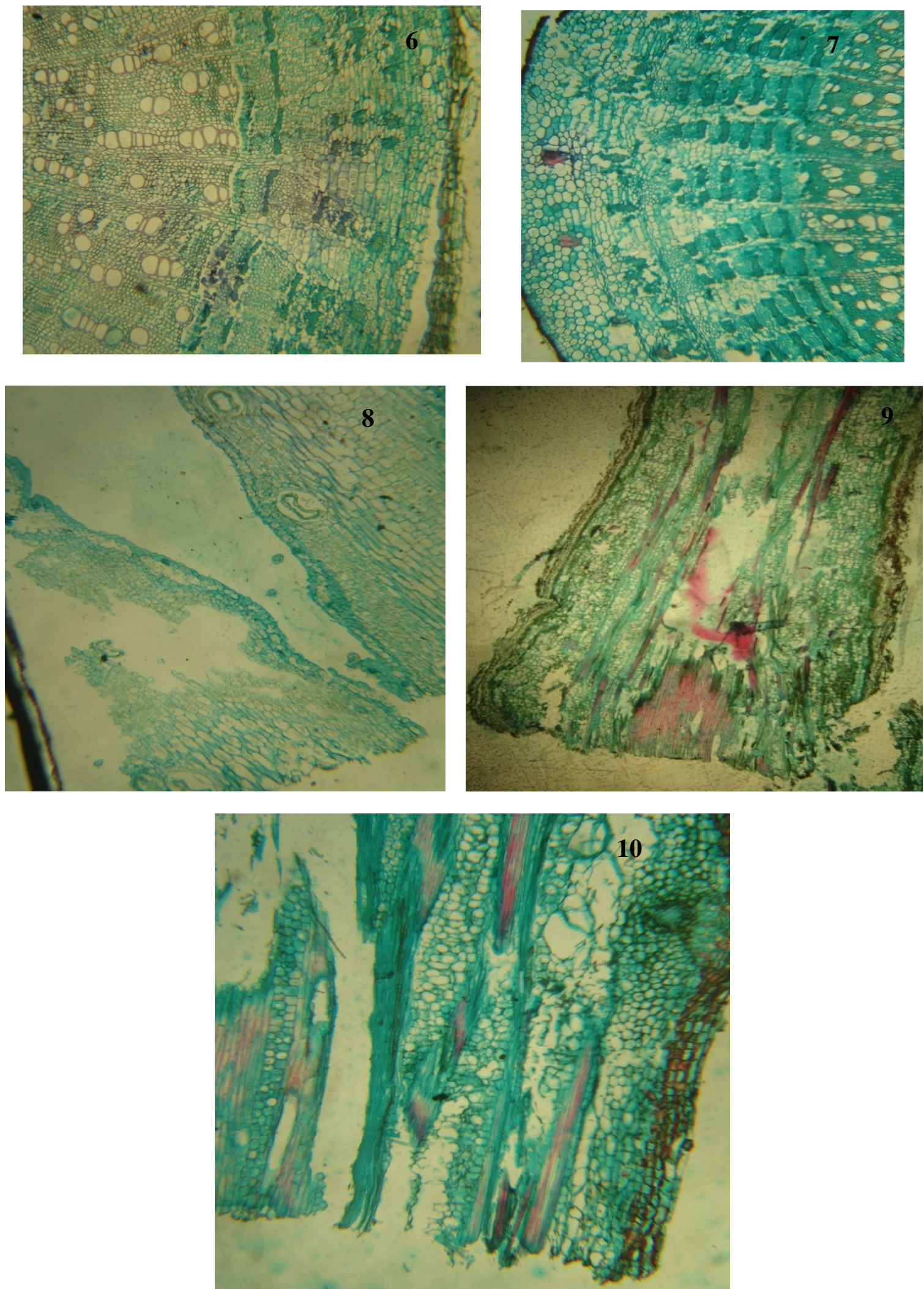

Figs. 6-7. The transverse section of the anatomical feature of $A$. squamosa and A. glauca, respectively, with the vessels clearly shown at magnification of $\times 10$. Fig. 8 . The longitudinal section of $A$. senegalensis with tracheid. Figs. 9-10. The longitudinal section of the wood anatomical feature of $A$. muricata and $X$. aethiopica, respectively. 
Tab. 1. Dimension of the tissues of the woods

\begin{tabular}{ccc}
\hline Scientific Names & Vessel diameter $(\mu \mathrm{m})$ & Fibre length $(\mu \mathrm{m})$ \\
\hline Annona glauca & $200-225$ & $100-150$ \\
\hline Annona muricata & $200-225$ & $225-275$ \\
\hline Annona senegalensis & $75-125$ & $50-125$ \\
Annona squamosa & $175-250$ & $150-275$ \\
Cleistopholispatens & $200-250$ & $150-225$ \\
Greenwayodendron suaviolis & $225-250$ & $75-200$ \\
\hline Monodora tenuifolia & $200-275$ & $225-250$ \\
Xylopia aethiopica & $225-250$ & $125-175$ \\
\hline
\end{tabular}

Tab. 2. Comparison of some qualitative anatomical feature of some Annonaceae species

\begin{tabular}{cccccccc} 
Taxa & \multicolumn{7}{c}{ Characterscodes } \\
Annona glauca & 1 & 2 & 3 & 4 & 5 & 6 & 7 \\
Annona squamosa & + & - & + & - & + & + & + \\
Annona senegalensis & - & + & + & + & - & + & + \\
Annona muricata & - & + & + & + & - & - & - \\
Xylopia aethiopica & + & - & + & - & - & + & + \\
Cleistopholis patens & + & + & + & - & - & + & + \\
Mondora tenuifolia & - & - & + & - & - & + & + \\
Greenwayodendron suaviolis & - & + & + & - & - & + & + \\
\hline
\end{tabular}

Legend to character codes: $1=$ vessels solitary, $2=$ fibres septate, $3=$ rays above $10,4=$ rays storied, $5=$ axial parenchyma, $6=$ vessels dense and numerous, $7=$ pith present and numerous.

fibre length. Monodora tenuifolia had the highest vessel diameter ranging between $200-275 \mu \mathrm{m}$ while for the other species; the variation is between $75-250 \mu \mathrm{m}$. The fibre length also varies as it ranges between 50 $225 \mathrm{um}$ in $A$. senegalensis, $A$. sauamosa and $A$. muricata.

\section{Discussions}

Generally, the wood anatomy of Annonaceae observed agreed with the wood anatomical structure of other family found in the literatures. Evidence of common evolutionary origin in the Annona species had been reported (Folorunso and Olorode, 2006 a). According to them, there are intrageneric relationships among the Annonas (Folorunso and Olorode, 2006 a, b).

A typical Annonaceae wood shows growth ring that are distinct to indistinct, diffuse porosity and solitary. In this study, the vessels are exclusively solitary in some species while predominantly in some but clearly outlined in others. Vessels have scalariform or simple perforation plates in some species and this corroborate the work of Folorunso (2011) who observed that the vessels are of two types, that is, short-wide with simple pits and the long-narrow with opposite pair pitting arrangements of bordered. Generally, intervessel pit are opposite to alternate in species with simple perforation, and distinctly bordered, opposite to scalariform in species with scalariform perforation. Non-septate of fibretracheid with distinctly bordered pits in Annonaceae agreed with the study of Butterfield and Meylan (1976) on wood anatomical feature of Epacrids. Butterfield and Meylan (1976) were able to show that the fibre-tracheid is characteristically non- septate with distinctly bordered pits and often thin to very thick walls. Tracheids are generally scanty and clearly outlined when present.

Furthermore, Chattawa (1956) on crystalliferous cells in Monotoca eliptica and Trochocarpa laurina, observed that uniseriate rays consisting of upright cells are always present and multiseriate rays recorded in few cases, as this also agreed with the present study of Annonaceae. Pith cells are in most cases oval but sometimes circular in outlined, pith cells are numerous and clearly noticed when present.

The wood anatomical structures of the species studied show much similarity. Example is the presence of 
growth ring, distinct/indistinct, diffuse porosity, and solitary vessels with round to angular outlined, scalariform and or simple perforation, fibre pits and the presence of uniseriate rays with less common multiseriate rays. According to Ayensu (1970 b), in the study of root anatomical feature of Dioscorea rotundata, and Dioscorea cayanensis, Mbagwu and Edeoga (2006) in the study of anatomical feature of Vigna spp. stated that all the features mentioned above strengthen the reliability of anatomical character in systematic botany.

The significant wood anatomical evidence observed in this study suggest that most of the Annonaceae species studied are primitive because simple vessel perforation plates are common in them but some species have reticulate perforation palates with intervessel pits near each other. This observation was also in agreement with the observation of Folorunso (2011). Diffuse porous wood is found nearly in all the species. Growth ring are generally present, but distinct in $A$. glauca and $A$. squamosa. Furness et al. (2002) emphasized the variability of vessels which is multiple and piths which is septate in their study of Magnoliales. More so, vessel element with simple perforation plates, and epidermal cell with single crystal are common in the family but varied depending on the species. However, this agreed with the study of Soltis (1990) on anatomical characteristic of Ericaceae. Therefore, this present study agreed with the previous studies carried out on the family.

\section{Conclussion}

The present study reported comparable results to those of previous studies, carried out on the genera. The anatomical structures of the investigated species' wood show several similarities. The wood anatomical characters observed in this study is of taxonomic importance in the identification of the species of Annonaceae studied. This leads to a grouping of the species based on presence or absence of some these taxonomic characters as this would provide a better understanding of wood anatomy of the family.

\section{References}

Ayensu ES (1970b). Comparative anatomy of Dioscorea rotundata and Dioscorea cayanensis. J Linn Soc (Bot) 63 (1):127-136.
Bridg H (1993a). El Cultivo de la Cherimoya Annona cherimola. Agrodesarrollo 4:329-344.

Butterfield BG, Melyan BA (1976). The occurrence of septate fibres in some New Zealand woods. New Zealand Journal of Botany 14:123-130.

Chattaway MW (1956). Crystal in woody tissues, Part II. Trop. Woods 104:100-104.

Erkens RHJ, Chatrou LW, Koek-Noorman J, Maas JW, Maas PJM (2007). Classification of a large and widespread genus of Neotropical trees, Guatteria (Annonaceae) and its three satellite genera Guatteriella, Guatteriopsis and Heteropetalum. Taxon 56:757-774.

Folorunso AE (2011). Diversity in the Stem Anatomy and Tissues of Several Species of Annona (Annonaceae) in Nigeria. Not Sci Biol 3(3):20-32.

Folorunso AE, Olorode O (2006a). Crude protein electrophoresis of some species of Annona in Nigeria. Ife J Sci 8(1):15-18.

Folorunso AE, Olorode O (2006b). Biosystematic studies in Annonaceae I. Vegetative and floral morphological studies of some species of Annona in Nigeria. Res J Bot 1(3):118124.

Furness CA, Rudall PJ, \& Sampson (2002). Evolution of Microsporogenesis in Angiospers. International journal of Plant Science 163:235-260.

Goodrich KR, Raguso RA (2009). The olfactory component of floral display in Asimina and Deeringothamnus (Annonaceae). New Phytologist 183:457-469.

Mbagwu FN, Edeoga HO (2006). Anatomical Studies on the Roots of Some Vigna savi Species (Leguminosae Papilionoideae). Agri J 1(1):8-10.

Olatunji OA (1992). Comparative wood anatomy of some species of Zanthoxylum (Rutaceae) in Nigeria. Nigerian J Bot 5:1-14.

Soltis SD (1990). The relation between xylem conduit diameter and cavitation caused by freezing. American Journal of Botany 86:1367-1372.

Su YCF, Smith GJD, Saunders RMK (2008). Phylogeny of the basal angiosperm genus Pseuduvaria (Annonaceae) inferred from five chloroplast DNA regions, with interpretation of morphological character evolution. Molecular Phylogenetics and Evolution 48:188-206. 